\title{
Effectiveness of QR-Code in Learning during Covid-19 Pandemic
}

\author{
Syarifuddin ${ }^{1}$, Takdir $^{2}$, Meisaraswaty Arsyad ${ }^{3}$, Mirna $^{4}$ \\ \{hidayatullahsyarif05@gmail.com $\left.{ }^{1}\right\}$ \\ Muhammadiyah Sinjai Islamic Institute, Sinjai, South Sulawesi, Indonesia ${ }^{1,2,3,4}$
}

\begin{abstract}
To date, learning process in universities has turned out to be much preoccupied to listen and write. Now is the time for technology innovation to be applied in learning as students on the average have a smartphone. Lecturers as tutors and books as learning resources are replaced with $\mathrm{QR}$-Codes that can be accessed anytime and anywhere. The pandemic circumstance particularly supports learning innovation with QR-Code. The purpose of this research is to describe the effectiveness of using QR Code as media to optimize learning process. This research is pre-experiment with one-group pretest-posttest design. It was conducted by giving treatment to one particular class then comparing the circumstance before and after the treatment. The $n$-gain obtained had a value of $g=0.63$ which is categorized as moderate, learning motivation has positive result, and the response of students show positive result. Hence, it implies that there is an increase in students' learning achievement after the $\mathrm{QR}$ code has been used in learning process. This consequently leads to a conclusion that using QR Code is effective to optimize the learning process.
\end{abstract}

Keywords: Effectiveness, QR-code, media, learning process, covid-19

\section{Introduction}

The utilization of ICT in education realm has increased quite rapidly. This concept leads to the improvement of learning quality. Era of industrial revolution 4.0 demands efficiency, digitalization, and automation. It provides a golden opportunity for those who are able to apply information and communication technology in various fields, especially education. In the field of education, the function of ICT as a supplement began to shift to a necessity and compulsion [1]. Especially in the current covid-19 pandemic, government has issued regulations of dismissing all face-to-face educational activities, including universities, and taking alternative of online distance learning [2]. The problem among lecturers and students is the implication of a paradigm shift in the education system. The demand to increase professionalism in terms of knowledge mastery has become a homework for all education activists.

Nowadays, there are various means to support online learning such as online courses, computer-aided instruction, etc. It is taken into account that students in millennial era on the average have a smartphone so that the ICT operating skill is no longer a new and difficult thing for them. However, some of them fail to bring about the expected results. Surely, educators need to do their best to utilize ICT in optimizing the learning process, especially in mathematics instruction. According to [3], the selection of appropriate electronic media plays an important 
role to create an effective teaching learning process. QR Code is one of the ICT-based learning media.

The employment of Quick Response Code (QR Code) in learning is expected to empower students to play an active role in the learning process. The QR Code is a two-dimensional image that can present a data [4]. QR Code can send messages very fast, accessible and has high capacity and quality [5]. QR Code is free to generate and access data quickly and can be read with smartphone. Study of QR Code in education can be placed in the context of mobile learning. The QR Code consists of a black module on a white background that contains information such as text, URL links, and other data that can direct users to sources for more information about a specific place on a subject [6]. The QR Code enables the implementation of innovative systems that is based on paradigm of just-in-time learning and collaborative learning. Furthermore, the QR Code makes it possible to connect digital resources to printed text. It unlocks the opportunity to enrich paper-based subject matter. Enriched learning materials can motivate students with different learning needs that fundamentally leads to an effective learning process [8].

QR Code applications in education [9] include: (1) classroom management: providing contact information from lecturers to students, creating exam schedules, marking the identity of equipment in the classroom, (2) learning activities: creating books containing QR Codes, linking to educational multimedia sources on the internet (url) or Youtube, (3) assessments: creating quizzes using QR codes, and (4) finding literatures on the internet. The implementation of QR Code in learning is showed in Figure 1.

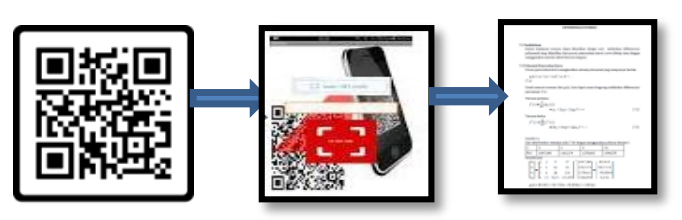

Fig. 1. QR code system workflow

Application of ICT, especially the QR Code, has been largely introduced to the realm of education and mostly exerts a positive influence in learning process both in school and in higher education. Research conducted by [11] shows that students' achievement through learning with QR codes is better than that through conventional learning. [12] also revealed that the application of QR codes is expected to create more efficient and effective mobile-based attendance tracking. In addition, [13] revealed that learning achievement of students who use of QR Codes is much better than those that do not. In the context of mathematics learning, however, only a few educational institutions have utilized QR Code technology to date, the number keeps increasing nevertheless, such as Hangzhou Dianzi University, China [14], University of Wollongong, Australia [4] and Institut Pertanian Bogor (IPB) University, Indonesia. However, under the current circumstance of covid-19 pandemic, there is a need for learning innovation. QR Code technology is one of the alternatives to actualize and optimize learning process in mathematics teacher education program to be more effective and efficient. 


\section{Method}

This research is pre-experiment with one-group pretest-posttest design. It was conducted by giving treatment to one particular class then comparing the circumstances before and after the treatment. The samples consisted of 24 undergraduate students majoring in mathematics teacher education program. The instruments used were achievement test and a questionnaire designed to evaluate the effectiveness of QR Codes in mathematics learning process. The achievement test was used to assess comprehension level of students, while questionnaire was used to assess students' learning motivation and response. The data was descriptively analyzed to determine the criteria of effectiveness based on indicators. Effectiveness criteria for each indicator are: (1) there should be improvement in test score after applying the QR Code, n-gain should at least in the moderate category, (2) learning motivation should belong to, at least, good category and (3) student response should, at least, be in the positive category.

\section{Results and Discussion}

\subsection{Learning achievement}

The result of the tests given to students before and after learning process using the QR Code is shown in Table 1.

Table 1. Categorization of students' study results before and after using QR Code

\begin{tabular}{|c|c|c|c|c|c|}
\hline \multirow{2}{*}{ Interval } & \multirow{2}{*}{ Category } & \multicolumn{2}{|c|}{ Pretest } & \multicolumn{2}{|c|}{ Posttest } \\
\hline & & $\mathbf{F}$ & $(\%)$ & $\mathbf{F}$ & $(\%)$ \\
\hline 91-100 & Very Good & 0 & 0.0 & 3 & 12.5 \\
\hline $75-90$ & Good & 1 & 4.2 & 18 & 75.0 \\
\hline $60-74$ & Moderate & 3 & 12.5 & 3 & 12.5 \\
\hline $40-59$ & Poor & 4 & 16.7 & 0 & 0.0 \\
\hline $0-39$ & Very Poor & 16 & 66.7 & 0 & 0.0 \\
\hline Total & & 24 & 100 & 24 & 100 \\
\hline
\end{tabular}

Based on Table 1 above, there were 16 or $66.7 \%$ students who had a very low initial knowledge before the use of QR Code media. Meanwhile, after the QR Code media applied, there were 18 or $75.0 \%$ students who had a good achievement with the mean score of 83.06 . It means that students gained good knowledge after learning with the QR Code.

The classification of the improvement of students' learning achievement is presented in Table 2 .

Table 2. Categorization of n-gain with QR Code media

\begin{tabular}{lccc}
\hline \multicolumn{1}{c}{ Coefficient of n-gain } & $\mathbf{N}$ & $\mathbf{( \% )}$ & Category \\
\hline $\mathrm{g}<0,3$ & 0 & 0.00 & Poor \\
$0,3 \leq \mathrm{g}<0,7$ & 22 & 91.7 & Moderate \\
$\mathrm{g} \geq 0,7$ & 2 & 8.3 & Good \\
\hline
\end{tabular}


Based on table 2, it appears that the increase in learning outcomes after using QR Code media is in the moderate category or $91.7 \%$ with an average increase (n-gain) of 0.63 .

\subsection{Students' learning motivation}

The results of the distribution of questionnaires about students' learning motivation after the use of QR Code learning media are shown in Table 3.

Table 3. Categorization of students' motivation after using QR Code

\begin{tabular}{llll}
\hline Interval & Category & $\mathrm{N}$ & $\%$ \\
\hline $81-100$ & Very Good & 6 & 25.0 \\
$61-80$ & Good & 15 & 62.5 \\
$41-60$ & Moderate & 2 & 8.3 \\
$21-40$ & Poor & 1 & 4.2 \\
$0-20$ & Very Poor & 0 & 0.0 \\
\hline \multicolumn{4}{l}{} \\
\hline
\end{tabular}

Table 3 implies that after using QR Code media, there were 15 students or $62.5 \%$ who had a good learning motivation with mean score of 80.56 and an average increase (n-gain) of 0.58 .

\subsection{Students' response}

The results of questionnaires about students' responses after using QR Code learning media are shown in Table 4.

Table 4. Categorization of students' responses after using QR Code

\begin{tabular}{llll}
\hline Interval & Category & $\mathrm{N}$ & $\%$ \\
\hline $48-63$ & Positive & 20 & 83.3 \\
$32-47$ & Tend to be Positive & 4 & 16.7 \\
$16-31$ & Tend to be Negative & 0 & 0 \\
$0-15$ & Negative & 0 & 0.0 \\
\hline \multicolumn{1}{c}{ Total } & & 24 & 100 \\
\hline
\end{tabular}

Based on table 4 above, there were 20 or $83.3 \%$ students who had a positive response to the QR Code with the mean score of 3.57.

\subsection{Effectiveness analysis}

Based on the aforementioned analysis that has been outlined earlier, it appears that the use of QR Code media has met the criteria of effectiveness, namely learning achievement, learning motivation, and students' response. Achievement criteria of the effectiveness of QR Code media can be seen in Table 5 . 
Table 5. Achievement criteria of effectiveness

\begin{tabular}{cllll}
\hline Media & \multicolumn{1}{c}{ Indicator } & Criteria & Score & Conclusion \\
\hline QR Code & Learning Achievement & & & \\
& $\bullet \quad$ Post-test mean score & $\bar{x}>74,9$ & 83,06 & Satisfied \\
& - Gain mean score & $\bar{x}>0,29$ & 0,63 & Satisfied \\
& Students' Learning Motivation & & & \\
& $-\quad$ Post-test mean score & $\bar{x}>74,9$ & 80,56 & Satisfied \\
& $-\quad$ Gain mean score & $\bar{x}>0,29$ & 0,58 & Satisfied \\
& $-\quad$ Students' response mean score & $\bar{x}>3,4$ & 3,57 & Satisfied \\
\hline
\end{tabular}

\subsection{Discussion}

QR Code learning media can improve students' learning achievement. This is because the characteristics of the QR Code promote students' understanding. Analysis of achievement test showed improvement from the pre-test to post-test results. Students' achievement before applying QR Code media is only in the poor category, while after applied the students' achievement increases to be good. The increase is in the moderate category. This is because students become highly motivated in learning. The high motivation that students have is shown by the eagerness and earnestness to success. Students have a strong desire to successfully master the lesson and get high grades in their learning activities. These qualities are seen from highmotivated and achieved students, such as trying to complete the given task thoroughly, not delaying the given job, willing to seek help from lecturer or his friends if having difficulty in the learning process. This is in accordance with the results of the study of [15] that students' motivation in learning mathematics increases due to the utilization of QR Codes.

Moreover, students responded positively to the learning atmosphere, the way lecturers teach, activities in the learning process, teaching materials used, and the tests given. This is because the students feel the benefits of the learning. Such benefits are the progress felt after learning and it is easier to understand the lesson presented using QR Code media. In addition, the positive impact felt by students is also seen from the ability of students to answer the questions presented. Some written comments said they were happy with the learning process with QR Code media, and suggested that the learning should be done on different topics.

\section{Conclusion}

The application of QR Code can improve efficiency and effectiveness in the learning process. Teachers and lecturers as the agents of change can create fun, innovative, and meaningful learning, especially mathematics and other subjects in general. In addition, students can gain a real and enjoyable learning experience which is also adaptive to the current development.

\section{Acknowledgements}

This research was supported by a grant from the Research and Community Service Institute (LP2M). We are grateful to all those who have participated in this research. 


\section{References}

[1] N. Saleh, S. Saud, M. Nur, and A. Asnur, "Utilization of QR-Code as a medium of foreign language learning in universities in Indonesia," no. July 2018, 2019.

[2] Kemdikbud, "PocketBook of Study Guide in The Covid-19 Pandemic," Ministry of Education,vol. 2019, pp. 1-58, 2020, [Online]. Available: https://www.kemdikbud.go.id/main/blog/2020/06/bukusaku-panduan-pembelajaran-di-masa-pandemi-covid19.

[3] A. Hilman, "Use of Ict Media To Improve Student Learning Outcomes of Smpn 3 Pagaden Use of Ict Media To Improve The Learning Outcomes of Public Junior High School Students 3 Pagaden," vol. 17, no. 3, pp. 295-315, 2018.

[4] Y. W. Chow, W. Susilo, J. Tonien, E. Vlahu-Gjorgievska, and G. Yang, "Cooperative secret sharing using QR codes and symmetric keys,” Symmetry (Basel)., vol. 10, no. 4, pp. 1-13, 2018, doi: 10.3390/sym10040095.

[5] G. Firmansyah and D. Hariyanto, "Journal of Physical Education, Health and Sport QR Code Based Teaching Materials for Organizational Classes and Game Systems,” J. Phys. Educ. Heal. Sport, vol. 6, no. 1, pp. 6-10, 2019.

[6] J. K. Lee, I. S. Lee, and Y. J. Kwon, "Scan \& Learn! Use of quick response codes \& smartphones in a biology field study," Am. Biol. Teach. , vol. 73, no. 8, pp. 485-492, 2011, doi: 10.1525/abt.2011.73.8.11.

[7] G. F. Orlando De Pietro, "No Title," in Mobile Tutoring for Situated Learning and Collaborative Learning in AIML Application Using QR-Code," 2012 Sixth International Conference on Complex, Intelligent, and Software Intensive Systems, 2012, pp. 799-805, doi: 10.1109/CISIS.2012.154.

[8] J. Li, Z. Shen, C. Yan, N. Dong, and H. Liang, "A method of image processing with QR code ablated on rough and highly reflective metal surface by laser," MATEC Web Conf. , vol. 232, 2018, doi: $10.1051 /$ matecconf/201823202024.

[9] D. Sugiana and D. Muhtadi, "Augmented Reality Type QR Code : Development of Learning Devices in the Era of Industrial Revolution 4. 0," pp. 135-140, 2019.

[10] D. Mardhiyana, U. Pekalongan, and U. Pekalongan, "Development of Materials Teaching Statistics Research Education Based Quick Response (QR) Code As An Effort to Improve," no. Rn D, pp. 6$15,2019$.

[11] S. Mustakim, "The Use of QR Code in Learning of Periodic Table Subject on the Class X SMA Labschool TadulakoUniversity"vol. 2, nov. 215-221, 2013.

[12] I. Labolo, "Implementation of QRCode for Absence of Paperless Office-Based Student Lectures," J. Inform. Upgris, vol. 5, no. 1, pp. 1-4, 2019, doi: 10.26877/jiu.v5i1.3689.

[13] R. De Fatima, R. Prestes, P. Henrique, F. Cordeiro, F. Periotto, and D. Baron, "QR Code technology in a sensory garden as a study tool," pp. 220-224, 2020.

[14] J. Lu, W. Cheng, S. Zhang, L. Li, Z. Yang, and C. C. Chang, "A novel aesthetic QR code algorithm based on hybrid basis vector matrices," Symmetry (Basel). , vol. 10, no. 11, 2018, doi: 10.3390/sym10110543.

[15] W. Widyasari, H. Sutopo, and M. Agustian, "QR Code-based Learning Development : Accessing Math Game for Children Learning Enhancement,” vol. 13, no. 11, pp. 111-124, 2019. 